\title{
Associated factors of malnutrition among African children under five years old, Bom Jesus, Angola
}

\author{
Fatores associados aos deficit nutricionais \\ entre crianças africanas menores de \\ cinco anos, Bom Jesus, Angola
}

Ema Cândida Branco FERNANDES'

Teresa Gontijo de CASTRO²

Daniela Saes SARTORELLI ${ }^{3}$

\section{A B S T R A C T}

\section{Objective}

To identify the determinants of wasting and stunting in children under five years old in the commune of Bom Jesus, Angola.

\section{Methods}

A population-based cross-sectional study was conducted with 742 children in 2010, and nutritional deficits were defined by World Health Organization criteria. Prevalence ratios and associated factors of wasting and stunting were estimated using Poisson regression with robust variance, using a conceptual hierarchical model.

\section{Results}

For both deficits, there were significant differences in the prevalence ratios according to the children's neighborhood and age. Boys and those children living in households whose water supply came from the river or lake, as well those with recent expulsion of parasites and infections were more likely to present stunting. Children of fathers with higher number of children or that which the fathers were not living at home and whose mothers were 25-34 years old were less likely to have wasting.

\footnotetext{
1 University Agostinho Neto, Medical School, Department of Public Health. Luanda, Angola.

${ }^{2}$ University of Auckland, Department of Paediatrics: Child \& Youth Health. Park Road, Grafton, Post Code 1023, Auckland, New Zealand. Correspondência para/Correspondence to: TG CASTRO. E-mail: <teresagcastro108@gmail.com>.

3 Universidade de São Paulo, Faculdade de Medicina de Ribeirão Preto, Departamento de Medicina Social. Ribeirão Preto, SP, Brasil.

Support: Sociedade Nacional de Combustíveis de Angola.

Article based on the master's thesis of ECB FERNANDES entitled "Determinantes da desnutrição infantil na Comuna de Bom Jesus, Angola: aplicação do modelo de análise hierarquizado". Universidade de São Paulo; 2014.
} 


\section{Conclusion}

It was identified independent variables from different levels of determination of malnutrition, standing out the basic sanitation conditions and family structure as important predictors of the nutritional deficits. The knowledge of the associated factors of malnutrition may contribute for subside public policies in planning interventions to improve the childhood nutrition status in Bom Jesus and communes with similar characteristics in Angola.

Keywords: Angola. Anthropometry. Child health. Malnutrition.

\section{RE S U M O}

\section{Objetivo}

Identificar os determinantes dos deficit estatural (índice altura/idade) e ponderal (indice peso/altura) entre crianças menores de cinco anos da Comuna de Bom Jesus, Angola.

\section{Métodos}

O estudo, transversal de base populacional, foi conduzido entre 742 crianças no ano de 2010 e os deficit nutricionais foram definidos de acordo com os criterios da Organização Mundial da Saúde. Razões de prevalência e fatores associados aos deficit nutricionais foram estimados mediante regressão de Poisson com variância robusta, utilizando-se modelo conceitual de análise hierarquizado.

\section{Resultados}

Para ambos os índices houve diferença significativa nas razões de prevalência de acordo com bairro de moradia e idade da criança. Crianças do sexo masculino e aquelas que residiam em domicílios cujo abastecimento de água era proveniente do rio ou lago, tão bem quanto aquelas que apresentaram expulsão de parasitas e infecções nos 15 dias anteriores à pesquisa, tiveram maior probabilidade de acometimento estatural. Para o deficit de peso/altura, menor probabilidade de acometimento foi observada entre crianças cujas mães tinham idade entre 25-34 anos e entre crianças cujo pai tinha elevado número de filhos ou que o pai não vivia no domicílio.

\section{Conclusão}

Foram identificadas variáveis independentes de diferentes níveis de determinação da desnutrição, destacando-se as condições sanitárias básicas e a estrutura familiar como importantes fatores associados aos deficit nutricionais. O conhecimento acerca dos determinantes da desnutrição pode subsidiar políticas públicas no planejamento de intervenções que visem melhorar o estado nutricional infantil em Bom Jesus e comunas com caracteristicas semelhantes em Angola.

Palavras-chave: Angola. Antropometria. Saúde da criança. Desnutrição.

\section{INTRODUCTION}

Despite the global trend for a reduction in nutritional deficit, this problem remains significant in some regions of the world ${ }^{1}$. In 2014, 159 million children under five years old were stunted (deficit of height for age), with a higher prevalence concentrated in the sub-Saharan Africa and Southern Asia. In the same year, wasting (deficit of weight for height), threatened the lives of 50 million children globally, and it was most prevalent in South Asia ${ }^{2}$. Among the under five years old of Angola the prevalence of stunting was 29\% (which 12\% was severe), and the wasting prevalence was $8 \%$ in $2007^{3}$. Stunting captures early chronic exposure to undernutrition while wasting captures acute undernutrition. Stunting and other forms of undernutrition are the major contributing factors to child mortality, disease and disability. A severely stunted child faces four times higher risk of dying, and a severely wasted child is nine times higher risk ${ }^{4}$. Children under two years old with stunting are more likely to have irreversible intellectual disabilities ${ }^{5}$ that negatively affect future academic success ${ }^{5-7}$, as well as the ability to generate income in the long term, with an average loss in adult annual income of $22 \% 5,8$. The consequence of stunting and its subsequent disproportionate and rapid weight gain on health 
later in life are referred to as the foetal programming concept: poor foetal growth, small size at birth and continued poor growth in early life followed by rapid weight gain later in childhood raises the risk of coronary heart disease, stroke, hypertension and type 2 diabetes. As stunted children enter adulthood with a greater propensity for developing obesity and other chronic diseases, the possibility of a burgeoning epidemic of poor health opens up, especially in transitional countries experiencing increasing urbanization and shifts in diet and lifestyle ${ }^{4,5}$. This epidemiological transition could create new economic and social challenges in many low and middle-income countries where stunting is prevalent, especially among poorer population groups 4 . The increased awareness of stunting's magnitude and devastating consequences has resulted in its being identified as a major global health priority and the focus of international attention at the highest levels with global reduction targets set for 2025 and beyond .

The etiology of childhood nutritional deficit is multifactorial. In studies where determinants of the disease are sought, the complex hierarchical interrelationships among those determinants are best managed using the conceptual frameworks. Failure to take this aspects into consideration leads to underestimation of the effects of distal determinants that are critical for planning more efficient interventions ${ }^{9,10}$. In 1990, the United Nations Children's Fund (Unicef) proposed a research model to investigate the determinants of child malnutrition by grouping them into different hierarchy levels: distal (production and distribution of wealth, and cultural aspects), intermediate (influenced by the distal determinants, refers to the access to food and health care, and environmental conditions), and the proximal determinants (reflect the interrelationships between the distal and intermediate predictors, and involve food consumption and childhood morbidity) ${ }^{10}$.

The aim of this study was to identify the associated factors of wasting and stunting among children under five years old living in Bom Jesus, Angola, by using the conceptual hierarchical analysis. Knowledge of these factors may contribute for subside public policies in planning interventions to improve the childhood nutrition status in this commune and communes with similar characteristics in Angola.

\section{METHODS}

This was a population-based crosssectional study conducted in 2010 with children under five years old in the commune of Bom Jesus in Angola. This commune is part of the /colo and Bengo municipalities, and it is located in a rural area of the province of Luanda, with poor housing conditions and access to basic sanitation and health services ${ }^{11}$. An investigation about vaccination coverage among under 5 years old in this commune, conducted in the same year of the present study, registered also a low vaccination coverage $(37 \%)$ and that $52 \%$ of children had no immunization records ${ }^{12}$. The nutritional deficits represented a serious problem of public health among the under 5 years old in this area, with prevalence of $22 \%, 13 \%$ and $7 \%$, respectively, for the deficits height-for-age, weight-for-height and weight-for-age ${ }^{11}$.

As described elsewhere, briefly, we used a systematic sampling technique ${ }^{11}$ to select one third of households from each neighborhood (Bom Jesus commune has 10 neighborhoods). A total of 487 households were included, with a total of 766 children. Of these, $4.4 \%$ were absent from the commune, suffered from chronic diseases or presented outliers values for the anthropometric indexes (according to World Health Organization $[\mathrm{WHO}])^{13}$ and were therefore excluded from the analysis, resulting in a final sample of 742 children (96.9\% of the eligible children). Most children were male (54.3\%) and the mean age was 24.6 $( \pm 16.8)$ months old (for more details consult Fernandes et al. ${ }^{11}$ ). 
Data were collected between may and august of 2010 by previously trained medical students from the School of Medicine of the Agostinho Neto University in Angola. The independent variables (demographic and socioeconomic variables, environment and access to health services, family organization, child care capacity and morbidities in the last 15 days previously of the interview) were obtained by a structured interview that was conducted with mothers whenever possible. This study was approved by the Ethics Committee of the Faculty of Medicine of Ribeirão Preto of the Universidade de São Paulo (Process $n^{\circ}$ 357). Only individuals presenting a written or digital Informed and Free Consent Form signed by a parent or guardian were evaluated by this study.

The weight and height measurements were obtained, in duplicate, according to the recommendation of $\mathrm{WHO}^{13}$ and the mean value of the two measures was used. The weight for height and height for age indices were calculated in Z-score, using the WHO Anthro program, version 3.1.0 (Centers for Disease Control and Prevention, Atlanta, United States of America), that uses the WHO growth curves as reference ${ }^{14}$. Children were classified with stunting or wasting when height for age and weight for height indexes, respectively, were equal to or less than -2 Z-scores. Data were entered into Epi Info ${ }^{\circledR}$ (Centers for Disease Control and Prevention, Atlanta, United States of America), version 3.5.1, and transferred to the Stata ${ }^{\circledR}$ (StataCorp., College Station, Texas, United States of America) 10.0 software program for statistical analysis.

We set wasting and stunting as the outcome variables. We first conducted a univariate regression analysis and tested each variable separately to select those to be used in the conceptual hierarchical model adapted from Unicef $^{10}$. We calculated the gross Prevalence Ratio (PR) and a Confidence Interval of 95\% $(95 \% \mathrm{Cl})$ using the Wald statistic. Independent variables with $p$-value $<0.20$ in the univariate analysis were selected for the multivariate analysis, and were grouped into distal, intermediate and proximal levels (Figure 1). Children with complete data were included in the multiple hierarchical analysis using Poisson regression with robust variance ${ }^{15}$ in order to identify the associated factors for each of the outcomes.

The adjustment for neighborhood of residence, child's age and child's gender was made at the beginning of fitting both models (stunting and wasting). We initially included in the models the variables selected from the univariate regression for the first block (socioeconomic) and kept those with a $p$-value $\leq 0.05$. Next, we added the variables 'environment' and 'access to local health services' (second block), keeping the variables that remained significant $(p \leq 0.05)$. We then added all variables from the third block (capacity for child care), keeping all variables with $p \leq 0.05$. Finally, following the same procedures described for the inclusion of variables from blocks 1, 2 and 3, we added the variables from the morbidity block and conducted a new analysis. Variables with $p$-values $\geq 0.05$ were removed from the models and re-evaluated one by one. None of them altered the PR of the variables that remained in the model by more than $10 \%$ and were therefore not reinserted or kept in the final models.

\section{RE S U L T S}

Tables 1 to 3 present the prevalence, gross PR and respective $95 \% \mathrm{Cl}$ between the dependent variable and independent variables which were associated $(p<0.20)$ in the univariate analysis. It was revealed that wasting was associated with the neighborhood of residence, with the child's age, parent's age, if the father was living at home/ had another family, number of father's children, if the child had a health card, source of water supply, mother's education level, number of mother's children, number of siblings under 5 years old and if the child had recent coughing. For stunting, significant associations were found 
for the neighborhood of residence, child's age and gender, father's ethnicity, if the father was living at home/had another family, number of father's children, mother's occupation, source of electricity, source of water supply, number of rooms at the house, mother's age, mother's education level, order of birth, and history of fever, vomiting, ear infection, diarrhea with mucus and blood and parasite expulsion in the last 15 days prior to the interview.

Adjusted for child's neighborhood age and gender

Distal level: Socioeconomic (block 1)

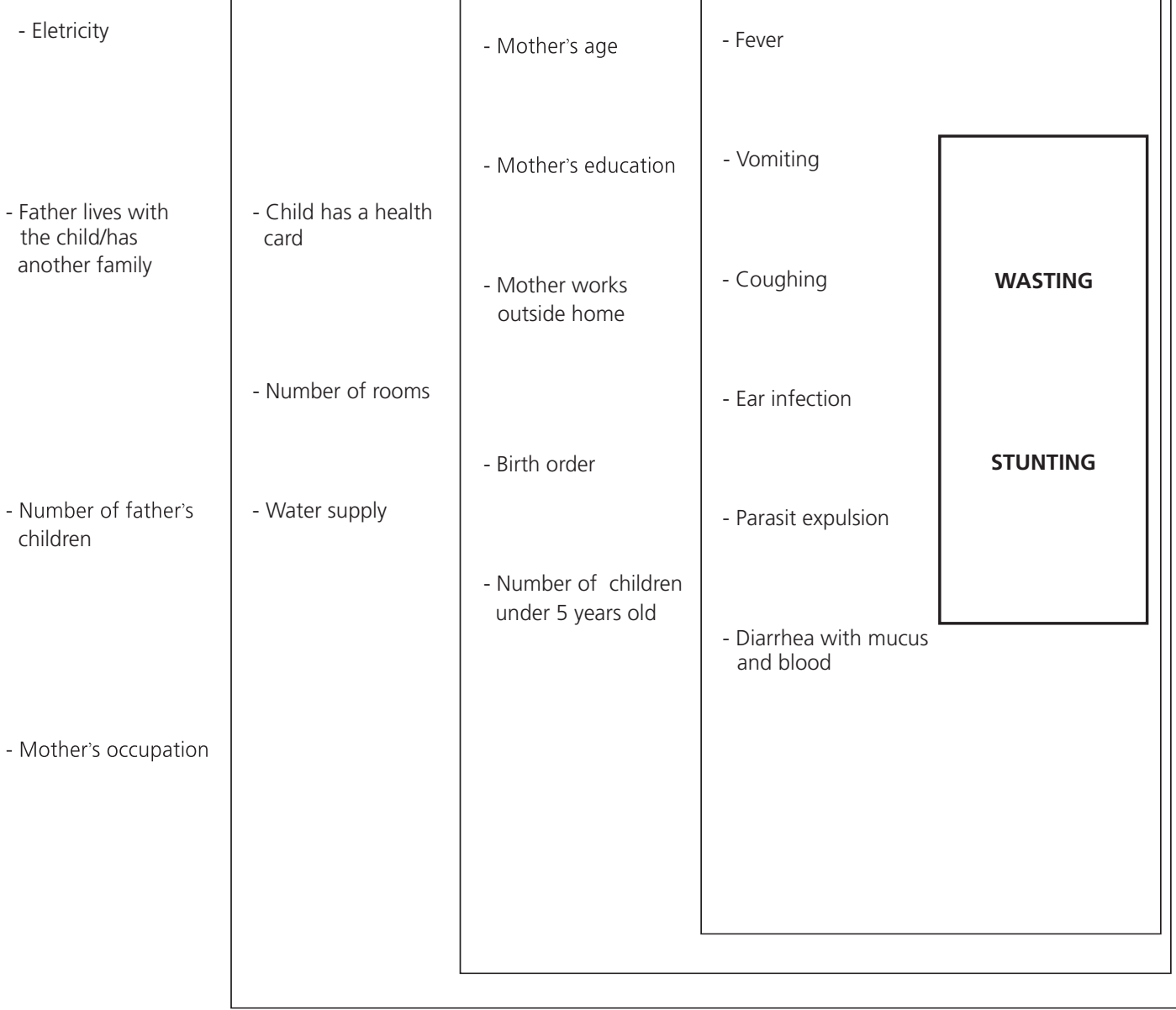

Figure 1. Conceptual hierarchial model to anlyze the predictors of nutritional déficits under five years old. Bom Jesus, Angola, 2010. Adapted from United Nations Children's Fund ${ }^{10}$. 
Table 1. Prevalence, ratio of gross prevalence and respective confidence intervals between nutritional deficits and demographic and socioeconomic variables in children under five years old. Bom Jesus, Angola, 2010.

\begin{tabular}{|c|c|c|c|c|c|}
\hline \multirow{2}{*}{ Variable } & \multirow{2}{*}{$\mathrm{n}$} & \multicolumn{2}{|r|}{ Wasting } & \multicolumn{2}{|r|}{ Stunting } \\
\hline & & $\%$ & PR $(95 \% \mathrm{Cl})$ & $\%$ & PR $(95 \% \mathrm{Cl})$ \\
\hline \multicolumn{6}{|l|}{ Neighborhood } \\
\hline Primeiro & 277 & 5.4 & 1 & 20.2 & 1 \\
\hline Segundo & 112 & 8.8 & $1.48(0.66-3.29)$ & 25.9 & $1.28(0.87-1.89)$ \\
\hline Honga Samba & 101 & 5.9 & $1.10(0.44-2.75)$ & 13.9 & $0.69(0.40-1.18)^{\dagger}$ \\
\hline Lucumbi & 76 & 13.2 & $2.43(1.14-5.19)^{*}$ & 32.9 & $1.63(1.10-2.42)^{*}$ \\
\hline Zambela & 54 & 5.6 & $1.03(0.31-3.43)$ & 22.2 & $1.11(0.63-1.91)$ \\
\hline Kassenda & 42 & 4.8 & $0.89(0.20-3.71)$ & 21.4 & $1.06(0.60-1.98)$ \\
\hline Kanakassassa and N'golome & 37 & 5.4 & $1.00(0.24-4.20)$ & 16.2 & $0.80(0.37-1.73)$ \\
\hline Matabuleiro and Coxe & 43 & 4.7 & $0.86(0.20-3.63)$ & 27.9 & $1.38(0.81-2.36)$ \\
\hline \multicolumn{6}{|l|}{ Child's age in months } \\
\hline $0-11$ & 171 & 9.4 & 1 & 10.5 & 1 \\
\hline $12-23$ & 176 & 9.7 & $1.03(0.54-1.98)$ & 25.0 & $2.38(1.43-3.94)^{*}$ \\
\hline $24-35$ & 138 & 2.9 & $0.31(0.11-0.91)^{*}$ & 29.7 & $2.82(1.70-4.69)^{*}$ \\
\hline $36-47$ & 139 & 2.9 & $0.31(0.11-0.90)^{*}$ & 26.6 & $2.53(1.51-4.24)^{*}$ \\
\hline $48-59$ & 118 & 6.8 & $0.72(0.32-1.64)$ & 19.5 & $1.85(1.05-3.28)^{*}$ \\
\hline \multicolumn{6}{|l|}{ Child's gender } \\
\hline Female & 339 & 6.5 & 1 & 19.1 & 1 \\
\hline Male & 403 & 6.7 & $0.97(0.56-1.67)$ & 25.4 & $1.33(1.01-1.74)^{*}$ \\
\hline \multicolumn{6}{|l|}{ Father's age } \\
\hline$<25$ & 182 & 12.1 & 1 & 22.0 & 1 \\
\hline $25-29$ & 145 & 8.3 & $0.68(0.35-1.34)$ & 21.4 & $0.97(0.64-1.47)$ \\
\hline $30-39$ & 201 & 4.0 & $0.33(0.15-0.72)^{*}$ & 20.9 & $0.95(0.65-1.40)$ \\
\hline$\geq 40$ & 154 & 3.2 & $0.27(0.10-0.69)^{*}$ & 20.1 & $0.92(0.60-1.39)$ \\
\hline N/A & 60 & - & - & - & - \\
\hline \multicolumn{6}{|l|}{ Father's ethnicity } \\
\hline Quimbundo & 459 & 7.0 & 1 & 20.0 & 1 \\
\hline Umbundo & 233 & 6.4 & $0.92(0.51-1.67)$ & 25.3 & $1.26(0.95-1.68)^{\dagger}$ \\
\hline Bakongo and others & 34 & 5.9 & $0.84(0.21-3.38)$ & 17.6 & $0.88(0.42-1.86)$ \\
\hline N/A & 16 & - & - & - & - \\
\hline \multicolumn{6}{|l|}{ Father lives at home/has another family } \\
\hline Lives with the child and does not have another family & 397 & 7.6 & 1 & 20.2 & 1 \\
\hline Lives with the child and has another family & 236 & 8.3 & $1.01(0.58-1.77)$ & 24.6 & $1.22(0.91-1.64)^{\dagger}$ \\
\hline Does not live with the child & 109 & 0.9 & $0.12(0.02-0.88)^{*}$ & 22.9 & $1.14(0.77-1.70)$ \\
\hline \multicolumn{6}{|l|}{ Number of father's children } \\
\hline 1 to 3 & 292 & 8.2 & 1 & 19.2 & 1 \\
\hline 4 to 6 & 260 & 7.3 & $0.89(0.50-1.59)$ & 20.8 & $1.08(0.77-1.51)$ \\
\hline$\geq 7$ & 170 & 3.5 & $0.43(0.18-1.03)^{\dagger}$ & 27.1 & $1.41(1.00-1.94)^{\dagger}$ \\
\hline N/A & 20 & - & - & - & - \\
\hline \multicolumn{6}{|l|}{ Mother's occupation } \\
\hline Farm worker & 230 & 7.0 & 1 & 23.9 & 1 \\
\hline Factory worker & 40 & 5.0 & $0.72(0.17-3.01)$ & 20.0 & $0.84(0.43-1.62)$ \\
\hline Nursing, teacher, public employee, clerk & 198 & 6.6 & $0.94(0.47-1.91)$ & 25.8 & $1.08(0.77-1.50)$ \\
\hline Home keeper and others & 274 & 6.6 & $0.94(0.49-1.81)$ & 17.9 & $0.75(0.53-1.05)^{\dagger}$ \\
\hline \multicolumn{6}{|l|}{ Electricity } \\
\hline From the network & 418 & 6.2 & 1 & 23.4 & 1 \\
\hline Current generator & 135 & 8.9 & $1.43(0.74-2.75)$ & 15.6 & $0.66(0.43-1.02)^{\dagger}$ \\
\hline No electricity & 189 & 5.8 & $0.94(0.47-1.85)$ & 23.3 & $0.72(0.72-1.36)$ \\
\hline
\end{tabular}

Note: ${ }^{*} p<0.05 ;{ }^{\dagger} p \geq 0.05$ and $<0.20$ (Wald test); $n=742$.

N/A: Information not Available; \%: Prevalence; PR: Prevalence Ratio; 95\% Cl: 95\% Confidence Interval. 
Table 2. Prevalence, ratio of gross prevalence and respective confidence intervals between nutritional deficits and environmental variables and access to local health services, capacity for caring for children under five years old. Bom Jesus, Angola, 2010.

\begin{tabular}{|c|c|c|c|c|c|}
\hline \multirow{2}{*}{ Variable } & \multirow{2}{*}{$n$} & \multicolumn{2}{|r|}{ Wasting } & \multicolumn{2}{|r|}{ Stunting } \\
\hline & & $\%$ & PR $(95 \% C l)$ & $\%$ & PR $(95 \% C l)$ \\
\hline \multicolumn{6}{|l|}{ Child has health card } \\
\hline No & 360 & 4.7 & 1 & 20.6 & 1 \\
\hline Yes & 382 & 8.4 & $1.77(1.00-3.14)^{\dagger}$ & 23.3 & $1.13(0.86-1.49)$ \\
\hline \multicolumn{6}{|l|}{ Water supply } \\
\hline Fountain or pit & 280 & 5.0 & 1 & 19.6 & 1 \\
\hline Lake or river & 462 & 7.6 & $1.52(0.83-2.77)^{\dagger}$ & 23.4 & $1.19(0.89-1.59)^{\dagger}$ \\
\hline \multicolumn{6}{|l|}{ Number of rooms } \\
\hline 1 & 537 & 7.1 & 1 & 23.1 & 1 \\
\hline 2 & 145 & 4.8 & $0.68(0.31-1.50)$ & 20.7 & $0.90(0.63-1.28)$ \\
\hline$\geq 3$ & 60 & 6.7 & $0.94(0.35-2.55)$ & 15.0 & $0.65(0.35-1.21)^{\dagger}$ \\
\hline \multicolumn{6}{|l|}{ Mother's age } \\
\hline $15-19$ & 76 & 13.2 & 1 & 15.8 & 1 \\
\hline $20-24$ & 253 & 8.7 & $0.66(0.33-1.33)$ & 24.1 & $1.53(0.87-2.68)^{\dagger}$ \\
\hline $25-29$ & 180 & 3.9 & $0.30(0.12-0.75)^{*}$ & 20.0 & $1.27(0.70-2.30)$ \\
\hline $30-34$ & 105 & 2.9 & $0.22(0.06-0.76)^{*}$ & 26.7 & $1.69(0.92-3.10)^{\dagger}$ \\
\hline$\geq 35$ & 124 & 5.6 & $0.43(0.17-1.08)^{\dagger}$ & 21.0 & $1.33(0.70-2.47)$ \\
\hline N/A & 4 & - & - & - & - \\
\hline \multicolumn{6}{|l|}{ Mother's education level } \\
\hline Illiterate & 307 & 5.0 & 1 & 20.5 & 1 \\
\hline 1 to 4 & 199 & 6.1 & $1.21(0.59-2.49)$ & 25.5 & $1.25(0.90-1.72)^{\dagger}$ \\
\hline$\geq 5$ & 236 & 8.9 & $1.77(0.91-3.46)^{\dagger}$ & 19.9 & $0.97(0.69-1.38)$ \\
\hline \multicolumn{6}{|l|}{ Mother works outside the house } \\
\hline No & 373 & 7.0 & 1 & 19.0 & 1 \\
\hline Yes & 369 & 6.2 & $0.89(0.52-1.54)$ & 24.9 & $1.31(1.00-1.72)^{\dagger}$ \\
\hline \multicolumn{6}{|l|}{ Number of mother's children } \\
\hline 1 to 2 & 276 & 7.6 & 1 & 20.3 & \\
\hline 3 to 4 & 289 & 7.3 & $0.96(0.53-1.71)$ & 24.2 & 1 \\
\hline 5 to 12 & 177 & 4.0 & $0.52(0.23-1.20)^{\dagger}$ & 20.9 & $1.19(0.88-1.63)$ \\
\hline Birth order & & & & & $1.03(0.71-1.49)$ \\
\hline First & 390 & 5.9 & 1 & 22.3 & \\
\hline Second & 169 & 6.5 & $1.11(0.55-2.21)$ & 14.2 & 1 \\
\hline$\geq$ Third & 183 & 8.2 & $1.39(0.74-2.60)$ & 28.4 & $0.64(0.42-0.96)^{*}$ \\
\hline Number of siblings under 5 years old & & & & & $1.27(0.95-1.71)^{\dagger}$ \\
\hline None & 260 & 8.1 & 1 & 22.3 & 1 \\
\hline 1 & 381 & 5.2 & $0.65(0.36-1.17)^{\dagger}$ & 21.3 & $0.95(0.71-1.28)$ \\
\hline$\geq 2$ & 101 & 7.9 & $0.98(0.45-2.14)$ & 23.8 & $1.07(0.70-1.62)$ \\
\hline
\end{tabular}

Note: ${ }^{*} p<0.05 ;{ }^{\dagger} p \geq 0.05$ and $<0.20$ (Wald test). $\mathrm{n}=742$.

N/A: Information not Available; \%: Prevalence; PR: Prevalence Ratio; 95\%Cl: 95\% Confidence Interval.

Table 4 shows the results of the final multiple models for wasting and stunting, adjusted for neighborhood of residence, age and gender. Compared to the children living in the neighborhood of Primeiro, children living in Lucumbi had higher PR of stunting and the wasting PR was more than twice larger. Children of 24-35 months old had a lower PR of wasting when compared with the group of children younger than 12 months old. Children with 12 months old or older, compared to those under 12 months old, had higher PR of stunting. The PR of stunting was higher in male children. At the distal level a lower PR of wasting was observed among those whose fathers were not living at home and that the father had a smaller number 
Table 3. Prevalence, ratio of gross prevalence and respective confidence intervals between nutritional deficits and variables related to morbidity during the previous 15 days in children under five years old. Bom Jesus, Angola, 2010.

\begin{tabular}{|c|c|c|c|c|c|}
\hline \multirow{2}{*}{ Variables } & \multirow{2}{*}{$\mathrm{n}$} & \multicolumn{2}{|r|}{ Wasting } & \multicolumn{2}{|r|}{ Stunting } \\
\hline & & $\%$ & PR $(95 \% \mathrm{Cl})$ & $\%$ & PR $(95 \% \mathrm{Cl})$ \\
\hline \multicolumn{6}{|c|}{ Morbidity during the previous 15 days } \\
\hline \multicolumn{6}{|l|}{ Fever } \\
\hline No & 491 & 7.1 & 1 & 20.2 & 1 \\
\hline Yes & 251 & 5.6 & $0.78(0.43-1.43)$ & 25.5 & $1.26(0.96-1.67)^{\dagger}$ \\
\hline \multicolumn{6}{|l|}{ Vomiting } \\
\hline No & 688 & 6.4 & 1 & 21.1 & 1 \\
\hline Yes & 54 & 9.3 & $1.45(0.60-3.50)$ & 33.3 & $1.58(1.06-2.40)^{*}$ \\
\hline \multicolumn{6}{|l|}{ Coughing } \\
\hline No & 463 & 7.8 & 1 & 20.5 & 1 \\
\hline Yes & 128 & 4.7 & $0.60(0.32-1.11)^{\dagger}$ & 24.4 & $1.19(0.90-1.56)$ \\
\hline \multicolumn{6}{|c|}{ Ear infection } \\
\hline No & 694 & 6.8 & 1 & 21.2 & 1 \\
\hline Yes & 48 & 4.2 & $0.62(015-2.46)$ & 33.3 & $1.57(1.03-2.41)^{*}$ \\
\hline \multicolumn{6}{|c|}{ Diarrhea with mucus and blood } \\
\hline No & 667 & 6.7 & 1 & 20.8 & 1 \\
\hline Yes & 75 & 5.3 & $0.79(0.29-2.14)$ & 32.0 & $1.54(1.07-2.20)^{*}$ \\
\hline \multicolumn{6}{|c|}{ Parasite expulsion } \\
\hline No & 700 & 6.4 & 1 & 21.0 & 1 \\
\hline Yes & 42 & 9.5 & $1.48(0.56-3.93)$ & 38.1 & $1.81(1.20-2.74)^{*}$ \\
\hline
\end{tabular}

Note: $\mathrm{n}=742 ;{ }^{*} p<0.05 ;{ }^{\dagger} p \geq 0.05$ and $<0.20$ (Wald test).

N/A: Information not Available; \%: Prevalence; PR: Prevalence Ratio; 95\%Cl: 95\% Confidence Interval.

of children. At the intermediate level a lower PR of wasting was observed among children with mothers aged 25 to 34 (compared to children with adolescent mothers) and higher PR of stunting was identified among children whose water supply came from the river or lake (compared to those supplied by fountain or pit). At the level proximal children presenting recent parasite expulsion or ear infection had a higher PR of stunting.

\section{DISCUSSION}

In line with our original hypothesis, the results of the present study indicate that the variability in the prevalence of childhood nutritional deficits is linked to a complex set of factors. Recent study conducted in India ${ }^{16}$, criticizes the disproportionate focus on 'demandside' interventions with an aim to addressing 'proximal' risk factors for stunting, leaving the broader structural and supply-side determinants largely untouched. The urgent need to bolster a concerted support-led strategy focused on improving the structural and multifactorial determinants of child undernutrition in India.

Disparities in the prevalence of nutritional deficit in the childhood were observed in other studies when taking into account area of residence and income ${ }^{4,17}$. Kennedy et $a{ }^{1 .}{ }^{18}$, in a study conducted in Angola, Central African Republic and Senegal, reported that stunting was higher among rural (relative to simple urban) dwellers. However, when they divided the population using the wealth index (which is based on quality of life and ownership of goods), poor children in urban areas were just as likely to have wasting and stunting as children from rural areas with the same economic conditions. Despite the rural localization of the commune, with poor housing conditions and access to basic sanitation and health services ${ }^{11}$, we observed that the likelihood of suffering from the different deficit 
Table 4. Associated factors of wasting and stunting among children under five years old. Bom Jesus, Angola, 2010.

\begin{tabular}{|c|c|c|c|c|}
\hline \multirow{2}{*}{ Variables } & \multicolumn{2}{|c|}{ Wasting $(n=718)$} & \multicolumn{2}{|c|}{ Stunting $(n=742)$} \\
\hline & PR $(95 \% \mathrm{Cl})$ & $p$ & PR $(95 \% \mathrm{Cl})$ & $p$ \\
\hline \multicolumn{5}{|l|}{ Neighborhood } \\
\hline Primeiro & 1 & - & 1 & - \\
\hline Segundo & $1.67(0.76-3.66)$ & 0.204 & $1.26(0.85-1.84)$ & 0.247 \\
\hline Honga Samba & $1.15(0.48-2.98)$ & 0.703 & $0.61(0.36-1.04)$ & 0.069 \\
\hline Lucumbi & $2.55(1.22-5.32)$ & 0.013 & $1.59(1.08-2.33)$ & 0.019 \\
\hline Zambela & $1.03(0.31-3.37)$ & 0.962 & $1.08(0.63-1.83)$ & 0.791 \\
\hline Kassenda & $1.09(0.27-4.45)$ & 0.909 & $1.02(0.58-1.85)$ & 0.936 \\
\hline Kanakassassa and N'golome & $1.23(0.29-5.27)$ & 0.785 & $0.72(0.33-1.56)$ & 0.403 \\
\hline Matabuleiro and Coxe & $1.14(0.27-4.76)$ & 0.856 & $1.37(0.80-2.36)$ & 0.250 \\
\hline \multicolumn{5}{|l|}{ Child's age } \\
\hline $0-11$ & 1 & - & 1 & \\
\hline $12-23$ & $1.20(0.62-2.33)$ & 0.593 & $2.53(1.53-4.18)$ & 0.000 \\
\hline $24-35$ & $0.33(0.11-0.99)$ & 0.047 & $2.91(1.76-4.81)$ & 0.000 \\
\hline $36-47$ & $0.35(0.12-1.02)$ & 0.055 & $2.70(1.62-4.50)$ & 0.000 \\
\hline $48-59$ & $0.85(0.39-2.01)$ & 0.770 & $1.84(1.05-3.24)$ & 0.034 \\
\hline \multicolumn{5}{|l|}{ Child's gender } \\
\hline Female & 1 & - & 1 & \\
\hline Male & $0.90(0.52-1.55)$ & 0.691 & $1.36(1.04-1.77)$ & 0.025 \\
\hline \multicolumn{5}{|l|}{ Number of father's children* } \\
\hline 1 to 3 & 1 & - & - & - \\
\hline 4 to 6 & $0.81(0.43-1.51)$ & 0.506 & - & - \\
\hline$\geq 7$ & $0.36(0.14-0.97)$ & 0.044 & - & - \\
\hline \multicolumn{5}{|l|}{ Father lives with the child/has another family* } \\
\hline Lives with the child and does not have another family & 1 & - & - & - \\
\hline Lives with the child and has another family & $1.45(0.75-2.79)$ & 0.268 & - & - \\
\hline Does not live with the family & $0.16(0.02-0.82)$ & 0.044 & - & - \\
\hline Water supply** & - & - & & \\
\hline Fountain or pit & - & - & 1 & \\
\hline River or lake & - & - & $1.61(1.97-2.66)$ & 0.045 \\
\hline \multicolumn{5}{|l|}{ Mother's age ${ }^{\dagger}$} \\
\hline $15-19$ & 1 & - & - & - \\
\hline $20-24$ & $0.60(0,30-1.21)$ & 0.155 & - & - \\
\hline $25-29$ & $0.28(0.10-0.74)$ & 0.010 & - & - \\
\hline $30-34$ & $0.25(0.06-0.92)$ & 0.043 & - & - \\
\hline$\geq 35$ & $0.52(0.16-1.70)$ & 0.282 & - & - \\
\hline \multicolumn{5}{|l|}{ Parasite expulsion ${ }^{\ddagger}$} \\
\hline No & - & - & 1 & \\
\hline Yes & - & - & $1.46(1.38-2.16)$ & 0.041 \\
\hline \multicolumn{5}{|l|}{ Ear infection ${ }^{\ddagger}$} \\
\hline No & - & - & 1 & \\
\hline Yes & - & - & $1.59(1.18-2.43)$ & 0.031 \\
\hline
\end{tabular}

Note: Wasting: "Model 1: Adjusted for neighborhood, age and gender. ${ }^{\dagger}$ Model 2: Adjusted for neighborhood, age and gender, number of father's children, and if the father lives with the child or has another family; Stunting: ${ }^{* *}$ Model 1: Adjusted for neighborhood, age and gender; ${ }^{\ddagger}$ Model 2 : Adjusted for neighborhood, age and gender, and water supply.

PR: Prevalence Ratio; 95\% Cl: 95\% Confidence Interval.

varies between children living in different neighborhoods, which might be explained by differences in income, access to food and water supply ${ }^{4}$.
The increasing probability of stunting starting at 12 months, at older ages, is not surprising, given that this deficit results from a cumulative process that occurs over several 
episodes of dietary insufficiency and/or illnesses ${ }^{4}$, as also reported by other studies ${ }^{17,19}$. Similarly, the reduction in the probability of wasting after 24 months old is in accordance with the literature, that has reported that this deficit begins during pregnancy and continues approximately until 24 months, remaining stable afterwards ${ }^{20}$. The higher prevalence of stunting observed among the male children of Bom Jesus was also registered in studies conducted in sub-Saharan Africa ${ }^{4,21,22}$, and in Angola ${ }^{3,23}$, and might be partly explained by the greater susceptibility to infections among the boys ${ }^{24}$.

At the distal level of determination of the nutritional deficits among children from Bom Jesus, those ones that were not living with their father were less likely to have wasting. In a study conducted in Brazil ${ }^{25}$ a lower prevalence of this deficit was observed in children whose mothers were the head of the household. Although the father's presence in the home could increase the access to essential goods ${ }^{4}$, there are evidences that women are better manager of the house income, and tends to allocate more resources to the purchase of food ${ }^{21}$. In Bom Jesus, families were mostly traditional, including grandparents living in the home, which strengthens social support and child survival. Also, we observed that even when the father does not contribute with household costs, he keeps the status of head of household, which entitles him to a greater proportion of meals, to the detriment of wife and children. Similarly, children from families in which the father has the priority for food intake in Ethiopia were more likely to be stunted, when compared with children from families with equal food distribution ${ }^{21}$. In our study, the weak yet lower probability of observing wasting among children whose fathers had more than six children is probably related to polygamy. Traditionally, only men who have better financial means can have more than one wife and a large number of children.

At the intermediate level of determination, we observed a greater probability of wasting among children living in areas in which the water supply come from the river or lake, similar to findings in studies conducted in India, Africa and Brazil ${ }^{17,19,26-28}$. Evidence suggests that a deficient water supply, in terms of quantity and quality, negatively interfers with children's nutritional state, working as a vehicle for infections and intestinal parasites, and increasing family costs when purchasing water or physical exertion for children and women who must travel long distances to obtain it ${ }^{28}$. A lower prevalence of stunting was observed in children whose mothers were older than 25 years, compared to children of teenagers mothers in the intermediate level of determination. The observation that children born of young mothers are more likely to suffer ill health than children born of adult women has been previously reported ${ }^{4,26}$.

In the final results of the multivariate model, diarrhea was not independently associated with malnutrition, differently of the observed for other studies ${ }^{17,29}$. However, independent associations of malnutrition with other infections (ear infection and parasite expulsion) were registered. The greater probability of stunting in children with recent ear infections and parasite expulsion, observed at the proximal level of determination in our study, is related to the fact that infections can affect nutrition due to reduced food intake and greater energy expenditure, which weakens the immunity, thus exposing children to a greater risk of frequent, severe and prolonged illness ${ }^{4,30}$. Similar to our observation, a previous population-based study conducted in three communes of the Province of Bengo (Caxito, Mabubas and Ucua), Angola, investigated the prevalence of infections, anaemia and malnutrition among the age groups: 0-5 years old, 6-15 years old and $\geq 16$ years old. It was found that malnutrition was common among children (23.3\% under-weight, 9.9\% wasting and $32.2 \%$ stunting) and the infections were associated anaemia and malnutrition in this population ${ }^{23}$.

Evidence from 54 low and middle-income countries indicates that growth faltering on average begins during pregnancy and continues to about 24 months of age. This loss in linear growth is not recovered, and catch-up growth later during childhood is minimal. While the 
Unicef conceptual framework reflected a focus on children of preschool age, there is now more emphasis on policies and programs that support action before the age of 2 years, especially on maternal nutrition and health and appropriate infant and young child feeding and care practices ${ }^{2,4}$. At a proximal level of malnutrition determination, after birth, a number of practices can directly lead to poor growth including the inadequate breastfeeding practices such as non-exclusive breastfeeding; inappropriate complementary feeding, such as starting at the wrong age; poor access to or use of diverse types of food and inadequate intake of micronutrients ${ }^{2,4}$.

Breast feeding practices and dietary intake were not evaluated among the children of Bom Jesus, representing a limitation of our study. The other limitation of our study is, because it was a cross-sectional design, causal relation between the independent variables and the nutritional deficit cannot be concluded.

The study strengths include the fact that it is a population-based study, in which we evaluated also distal and intermediate predictors of childhood malnutrition in an Angolan commune, illustrating a complex system of interrelationships that are useful for identifying effective interventions in the field of childhood health and nutrition.

\section{CONCLUSION}

It was identified independent variables from different levels of determination of malnutrition, standing out the basic sanitation conditions and family structure as important predictors of the nutritional deficit among the children under 5 years old. The knowledge of the associated factors of malnutrition may contribute for subside public policies in planning interventions to improve the childhood nutrition status in Bom Jesus and communes with similar characteristics in Angola.

\section{CONTRIBUTORS}

ECB FERNANDES conceived the study hypothesis, participated of the data collection, data analysis, data interpretation and manuscript writing. TG CASTRO participated of the data analysis, data interpretation and manuscript writing. DS SARTORELLI conceived the study hypothesis, participated of the data analysis, data interpretation and manuscript writing.

\section{REFERE NCES}

1. Blössner M, Onis M. Malnutrition: Quantifying the health impact at national and local levels. WHO Environmental Burden of Disease Series, 12. Geneva: WHO; 2005.

2. United Nations Children's Fund. Annual Results Report 2015: Nutrition. New York: Unicef; 2015 [cited 2016 Aug 21]. Available from: http://www. unicef.org/publicpartnerships/files/2015ARR_ Nutrition.pdf

3. Angola. Ministério da Saúde. Relatório do inquérito sobre a nutrição em Angola. Luanda: Ministério da Saúde; 2007.

4. United Nations Children's Fund. Improving child nutrition: The achievable imperative for global progress. New York: Unicef; 2013 [cited 2013 Sept 20]. Available from: http://www.unicef.org/gambia/ Improving_Child_ Nutrition_-_the_achievable_ imperative_for_global_progress.pdf

5. Grantham-McGregor S, Cheung YB, Cueto S, Glewwe P, Richter L, Strupp B. Developmental potential in the first 5 years for children in developing countries. Lancet. 2007;369(9555):60-70. https:// doi.org/10.1016/S0140-6736(07)60032-4

6. De Onis ME, Branca F. Childhood stunting: A global perspective. Maternal Child Nutr. 2016;12(Suppl.1): 12-26.

7. Victora CG, Adair L, Fall C, Hallal PC, Martorell R, Richter $\mathrm{L}$, et al. Maternal and child undernutrition: Consequences for adult health and human capital. Lancet. 2008;371(9609):340-57. https://doi.org/ 10.1016/S0140-6736(07)61692-4

8. Martorell R, Melgar P, Maluccio JA, Stein AD, Rivera $J A$. The nutrition intervention improved adult human capital and economic productivity. J Nutr. 2010;140(2):411-4. https://doi.org/10.3945/jn. 109.114504

9. Victora CG, Huttly SR, Fuchs SC, Olinto MT. The role of conceptual frameworks in epidemiological analysis: A hierarchical approach. Int J Epidemiol. 1997;26(1):224-7.

10. United Nations Children's Fund. The state of the world's children: Focus on nutrition. New York: Unicef; 1998 [cited 2011 Apr 21]. Available from: http://www.unicef.org/sowc/archive/ENGLISH/ The $\% 20$ State $\% 20$ of $\% 20$ the $\% 20$ World's\%20Children \%201998.pdf 
11. Fernandes EC, Monteiro RA, Ribeiro LC, Sartorelli DS. Prevalence of nutritional deficits among children under five years of age in Angola. Rev Saúde Pública. 2013;47(4):817-20. https://doi.org/10. 1590/S0034-8910.2013047004576

12. Oliveira MFS, Martinez EZ, Rocha JSY. Factors associated with vaccination coverage in children $<5$ years in Angola. Rev Saúde Pública. 2014;48(6):906-15. https://doi.org/10.1590/ S0034-8910.2014048005284

13. World Health Organization. Training course on child growth assessment. Geneva: WHO; 2008 [cited 2012 Jan 20]. Available from: http://www.who.int childgrowth/training/module_h_directors_guide. pdf

14. World Health Organization. Multicenter Growth Reference Study Group. WHO child growth standards: Length/height-for-age, weight-for-age, weight-for-length, weight-for-height and body mass index-for-age: Methods and development. Gender: WHO; 2006 [cited 2012 Jan 20]. Available from: http://www.who.int/childgrowth/standards/ Technical_report.pdf

15. Barros AJ, Hirakata VN. Alternatives for logistic regression in cross-sectional studies: An empirical comparison of models that directly estimate the prevalence ratio. BMC Med Res Methodol. 2003;3(21):1471-2288.

16. Subramanian SV, Mejía-Guevara I, Krishna A. Rethinking policy perspectives on childhood stunting: Time to formulate a structural and multifactorial strategy. Maternal Child Nutr. 2016;12(Suppl.1):219-36.

17. Griffiths P, Madise N, Whitworth A, Matthews Z. A tale of two continents: A multilevel comparison of the determinants of child nutritional status from selected African and Indian regions. Health Place. 2004;2(10):183-99.

18. Kennedy G, Nantel G, Brouwer ID, Kok FJ. Does living in an urban environment confer advantages for childhood nutritional status? Analysis of disparities in nutritional status by wealth and residence in Angola, Central African Republic and Senegal. Public Health Nutr. 2006;9(2):187-93.

19. Fentahun W, Wubshet M, Tariku A. Undernutrition and associated factors among children aged 6-59 months in East Belesa District, northwest Ethiopia: A community based cross-sectional study. BMC Public Health. 2016;16(1):506. https://doi.org/ 10.1186/s12889-016-3180-0

20. Black RE, Victora CG, Walker SP, Bhutta Z, Christian $\mathrm{P}$, Onis $\mathrm{M}$, et al. Maternal and child undernutrition and overweight in low-income and middle-income countries. Lancet. 2013;382:427-51. https://doi. org/10.1016/S0140-6736(13)60937-X

21. Alemayehu M, Tinsae F, Kiday Haileslassie K, Seid O, Gebregziabher G, Henock Yebyo $\mathrm{H}$.
Undernutrition status and associated factors in under-5 children, in Tigray, Northern Ethiopia. Nutrition. 2015;31(7-8):964-70. https://doi.org/ 10.1016/j.nut.2015.01.013

22. Norris AS, Wrottesley S, Mohamed RS, Micklesfield LK. Africa in Transition: Growth trends in children and implications for nutrition. Ann Nutr Metab. 2014;64(Suppl.2):8-13. https://doi.org/10.1159/ 000365122

23. Sousa-Figueiredo JC, Gamboa D, Pedro JM, Fançony C, Langa AJ, Magalhães RJ, et al. Epidemiology of malaria, schistosomiasis, geohelminths, anemia and malnutrition in the context of a demographic surveillance system in Northern Angola. PLoS One. 2012;7(4):e33189. https://doi.org/10.1371/journal.pone.0033189

24. Muenchhoff M, Goulder PJR. Sex Differences in pediatric infectious diseases. J Infect Dis. 2014; 209(Suppl.3):S120-S6. https://doi.org/10.1093/ infdis/jiu232

25. Chagas DC, Silva AAM, Batista RFL, Simões VMF, Lamy ZC, Coimbra LC, et al. Prevalência e fatores associados à desnutrição e ao excesso de peso em menores de cinco anos nos seis municípios do Maranhão. Rev Bras Epidemiol. 2013;16(1):146-56.

26. Kabubo-Mariara J, Ndenge GK, Mwabu DK. Determinants of children's nutritional status in Kenya: Evidence from demographic and health surveys. J Afr Econ. 2009;18(3):363-87. https://doi. org/10.1093/jae/ejn024

27. Monteiro CA, Conde WL. Tendência secular da desnutrição e da obesidade na infância na cidade de São Paulo (1974-1996). Rev Saúde Pública. 2000;34(6Supl.):52-61.

28. Dangour AD, Watson L, Cumming O, Boisson $S$, Che $Y$, Velleman $Y$, et al. Interventions to improve water quality and supply, sanitation and hygiene practices, and their effects on the nutritional status of children. Cochrane Database Syst Rev. 2013;1(8):CD009382.

29. Gewa CA, Yndell N. Undernutrition among Kenyan children: Contribution of child, maternal and household factors. Public Health Nutr. 2012;15(6):1029-38. https://doi.org/10.1017/S13 $6898001100245 X$

30. Black RE, Allen LH, Bhutta ZA, Caulfield LE, de Onis M, Ezzati M, et al. Maternal and child undernutrition: Global and regional exposures and health consequences. Lancet. 2008;371(9608): 243-60. https://doi.org/10.1016/S0140-6736(07) 61690-0

Received: November 30, 2015 Final version: August 29, 2016 Approved: September 13, 2016 